Relations industrielles

Industrial Relations

\title{
Murphy, Marjorie, Blackboard Unions: The AFT and the NEA,
} 1900-1980

\section{Kenneth Wm. Thornicroft}

Volume 47, numéro 4, 1992

URI : https://id.erudit.org/iderudit/050821ar

DOI : https://doi.org/10.7202/050821ar

Aller au sommaire du numéro

Éditeur(s)

Département des relations industrielles de l'Université Laval

ISSN

0034-379X (imprimé)

1703-8138 (numérique)

Découvrir la revue

Citer ce compte rendu

Thornicroft, K. W. (1992). Compte rendu de [Murphy, Marjorie, Blackboard Unions: The AFT and the NEA, 1900-1980]. Relations industrielles / Industrial Relations, 47(4), 805-806. https://doi.org/10.7202/050821ar

Tous droits réservés (C Département des relations industrielles de l'Université Laval, 1992
Ce document est protégé par la loi sur le droit d'auteur. L'utilisation des services d'Érudit (y compris la reproduction) est assujettie à sa politique d'utilisation que vous pouvez consulter en ligne.

https://apropos.erudit.org/fr/usagers/politique-dutilisation/ 
congés fériés et des vacances. Au total le lecteur trouvera une somme importante d'informations utiles à la gestion quotidienne de la convention collective, à tout le moins au niveau des grands principes.

Les auteurs ont ramené dans la dernière partie du volume les matières qui intéressent le syndicat: clauses de sécurité syndicale, cotisation, obligations et droits du syndicat et de ses représentants en cas de grève et, enfin, discipline syndicale. Plus succincte que les précédentes, cette partie présente néanmoins une bonne synthèse des problèmes courants.

Collective Agreement Arbitration in Canada demeure un ouvrage bien structuré et qui se lit bien. On peut néanmoins regretter que chaque partie ne soit pas précédée d'une petite introduction qui faciliterait mieux le passage d'un chapitre à un autre et assurerait dès lors une meilleure vue d'ensemble. Dans la même mesure une conclusion récapitulative, cette fois sous chacun des chapitres, ne pourrait qu'être bénéfique.

Ce classique a fait ses preuves. II en est à sa troisième édition. Les praticiens sauront y trouver à nouveau un bon ouvrage de références. On ne peut par contre feindre d'ignorer qu'au fil des années l'ouvrage n'a pas su s'enrichir de notes bibliographiques; dans cette mesure le produit devient moins intéressant pour l'enseignement. Pour le lecteur québécois, il y a lieu d'insister à nouveau sur le fait que les solutions retenues dans les provinces de common law, en particulier de l'Ontario, ne sont pas toutes importables. En effet, plusieurs des règles qui y sont dégagées (ex. estoppel, waiver, etc.) sont des normes de common law inapplicables en contexte du droit québécois, à moins d'admettre que parce que notre droit du travail est d'inspiration américaine, il y a lieu de laisser libre-cours au phénomène de l'acculturation juridique démesurée.

Rodrigue BLOUIN

Université Laval

Blackboard Unions: The AFT and the NEA, 1900-1980, by Marjorie Murphy, Ithaca, New York, Cornell University Press, 1990, 284 p., ISBN 08014-2365-1

The conventional wisdom is that public sector collective bargaining took root during the social upheaval of the 1960s. While there may be some general truth in that view, collective bargaining by public school teachers is of much older conception. The first teachers' union can be traced to the late 1800s in Chicago. The New York teachers' strike in 1960 certainly was a turning point, but the first teachers' strikes occurred much earlier, in the mid-1940s. Blackboard Unions is the story of the genesis and growth of collective bargaining in American public schools; more specifically, it is the story of the still continuing rivalry between the two main teachers unions - the American Federation of Teachers (AFT) founded in 1916 and the older (1857) National Education Association (NEA). Much of the book focuses on the history of teacher bargaining in two American cities - Chicago and New York. In the case of Chicago teachers, Professor Murphy is tilling fertile ground, as this topic formed the subject matter of her doctoral dissertation (Murphy, 1981). 
There are unique aspects about teacher bargaining relative to other segments of the public sector. First, teaching (especially at the elementary level) was, and remains, a predominant vehicle for social mobility by women. Early teachers' unions were largely collectives of women led by women. In the early years, Murphy argues, this fact had profound implications for the way in which these organizations conducted their affairs. Second, few areas of the public sector are as deeply rooted in the local community as are schools. Thus, the marshalling of local community support was very frequently the foundation upon which bargaining gains were built. Murphy argues that over time, as teachers increasingly subscribed to the tenets "professionalism" (in the early years, a byword for anti-unionism; in later years, a by-word for greater teacher control over the delivery of educational services), the once-close ties between teacher unions and the local community began to unravel leading, especially in the case of many strikes in the 1960s and 1970s, to a schism between teachers and urban communities.

In many ways, the history of American teacher unionism is the history of the significant socio-economic and political problems of the past one hundred years universal suffrage, the Great Depression, the "red scare" and McCarthyism, civil rights, the Vietnam war, and, more recently, urban decline and government deficits. Each of these important issues affected teachers' working lives, at times furthering and in other times hindering, the cause of teacher unionism. Contrary to the direction of the Samuel Gompers-led AFL, Chicago teachers (AFT) formally opposed U.S. involvement in the First World War while the administrator-dominated NEA took a strong pro-war position. This ideological split between the two main teacher union federations continued unabated throughout the ensuing years, reflected in the differing positions taken by two organizations with respect to such issues as anti-communism, desegregation, local community control, and teacher competency testing.

Presently, although both the AFT and the much larger NEA enthusiastically embrace collective bargaining (including the right to strike), the two organizations, despite some occasional talk of unification, remain wary of each other. The AFT is formally affiliated with the AFL, whereas the NEA is not; a merger between the two organizations appears, at present, to be an unlikely prospect. Perhaps this is to the good, in much the same way that AFL and CIO rivalry sparked an increase in overall organizing activity during the 1930s and 1940s. Unlike the situation in Canada, the circle is not complete; only thirty-four American jurisdictions permit teacher bargaining and in many "bargaining states", teachers do not enjoy full bargaining rights (i.e., restricted scope of bargaining and most often no right to strike, Thornicroft, 1991). Teachers in "nonbargaining states" can be expected to pursue the bargaining option, as did teachers in Chicago and New York in an earlier time. Such efforts might well profit from a review of the record compiled by Professor Murphy; Blackboard Unions is a valuable contribution to our understanding of teacher unions and once again instructs us that we cannot understand the present without examining the past.

KENNETH WM. THORNICROFT

Memorial University of Newfoundland 